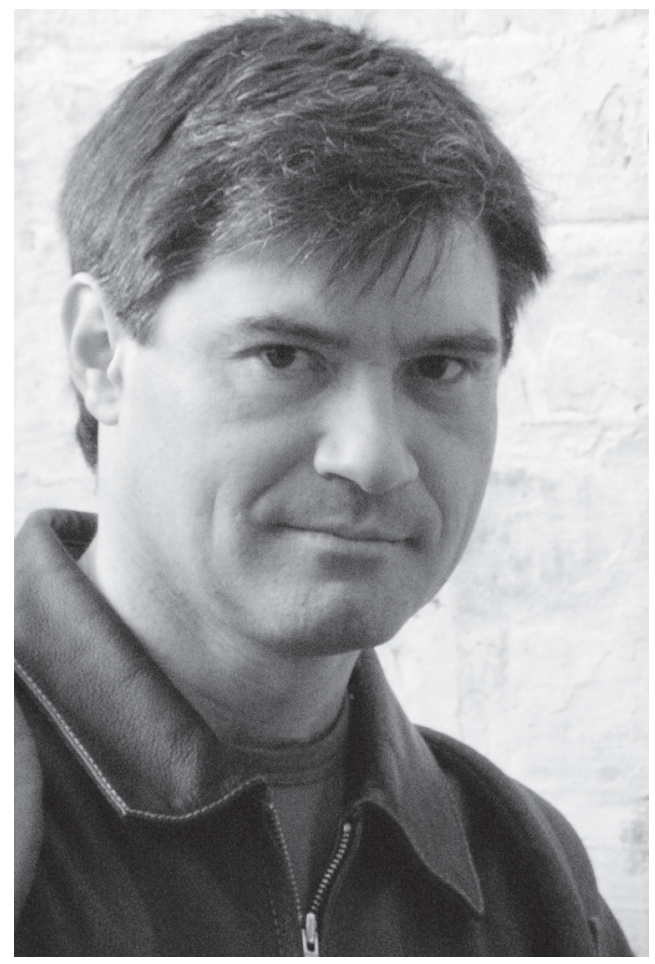

UDC: 35:624:330.131.7

DOI: https://doi.org/10.32689/2617-

2224-2019-17-2-56-64

Havrylov Andrii Volodymyrovych, post-graduate student of Public Administration Department, Interregional Academy of Personnel Management, 03039, Kyiv, Str. Frometivska, 2, tel.: +38 (067) 1857202. e-mail:andrii.havrylov@gmail.com

ORCID: 0000-0001-9486-6603

Гаврилов Андрій Володимирович, аспірант кафедри публічного адміністрування, Міжрегіональна Академія управління персоналом, 03039, м. Київ, вул. Фрометівська, 2, тел.: +38 (067) 18572 02, e-mail: andrii.havrylov@gmail.com

ORCID: 0000-0001-9486-6603

Гаврилов Андрей Владимирович, аспирант кафедри публичного администрирования, Межрегиональная Академия управления персоналом, 03039, г. Киев, ул. Фрометовская, 2, тел.: +38 (067) 185 72 02, e-mail: andrii.havrylov@gmail.com

ORCID: 0000-0001-9486-6603

\title{
ANALYSIS OF THE RISKS OCCURRING DURING CONSTRUCTION
}

Abstract. The article focuses on analyzing the risks that occur during implementation of investment construction projects. It analyzes the risk concept core, identifies risk sources, and classifies risks by the time of their occurrence (risks before the construction completion, risks after the construction completion). The article presents the methods used to analyze the risks that occur in the course of implementing investment construction projects: analogy method, statistical analysis method, sensitivity analysis method, examination method, diagram method, and normative method. Main consequences of risk realization are defined as well as ways of their mitigation. The article determines that of the principal importance is the impartial and unbiased analysis of the situation on the investment construction market in the context of the general state in a corresponding region and entire country. It is discovered that it is necessary to timely identify the risks happening during the project implementation. The risks' influence on the economic and operational components of construction is defined. The article reviews the basic mechanisms of risk management in cyclic stages lasting from the project 
commencement to its completion: identification and definition of a risk; development of measures to mitigate the revealed risks; implementation of the developed plan in the project; analyzing introduction of the project implementation supervision. Using the presented risk identification methods will encourage enhancing the effective realization of investment construction projects and decrease of actual expenses for project implementation, which are envisaged in the quantity surveying documents by revealing probable risks, their identification, and further fair allocation of the identified risks among the stakeholders of investment construction projects.

More detailed researches prioritize issues of developing a risk management methodology for implementation of investment construction projects and adoption of a matrix approach to risk allocation among the project realization stakeholders.

Keywords: construction, risk, risk management, violation, risk analysis methods, technological process, construction works, construction facility, investment construction project.

\section{АНАЛІЗ РИЗИКІВ, ЩО ВИНИКАЮТЬ У ПРОЦЕСІ БУДІВНИЦТВА}

Анотація. Проаналізовано ризики, що виникають у процесі реалізації інвестиційно-будівельних проектів. Розглянуто сутність поняття ризику, ідентифіковані джерела ризиків, здійснено класифікацію ризиків за сферою виникнення (ризики до завершення будівництва, ризики після завершення будівництва). Представлено методи аналізу ризиків, що виникають у процесі реалізації інвестиційно-будівельних проектів: метод аналогій, метод статистичного аналізу, метод аналізу чутливості, експертний метод, метод діаграм, нормативний метод.

Визначено основні наслідки реалізації ризиків та заходи щодо їх мінімізації. Встановлено, що принципове значення має об'єктивний та неупереджений аналіз ситуації, що склалася на інвестиційно-будівельному ринку в контексті загального стану у відповідному регіоні та в країні загалом. Виявлено необхідність своєчасної ідентифікації ризиків, які виникають під час реалізації проектів та визначено їх вплив на економічну та експлуатаційну складові будівництва. Розглянуто основні механізми управління ризиками, що представлені циклічними етапами, які тривають від початку і до моменту завершення проекту: виявлення і визначення ризику; розроблення кроків для зниження виявлених ризиків; впровадження розробленого плану в проект; проведення аналізу впровадження нагляду за реалізацією проекту. Використання представлених методів ідентинтифікації ризиків сприятиме підвищенню ефективності реалізації інвестиційно-будівельних проектів та зменшенню реальних витрат на реалізацію проектів, передбачених кошторисною документацією шляхом визначення можливих ризиків, їх ідентифікації та подальшому справедливому розподілі ідентифікованих ризиків між учасниками інвестиційно-будівельних проектів. 
У більш детальних дослідженнях пріоритетним є питання розроблення методології управління ризиками під час реалізації інвестиційно-будівельних проектів та запровадження матричного підходу до розподілу ризиків між учасниками реалізації проектів.

Ключові слова: будівництво, ризик, управління ризиками, порушення, методи аналізу ризиків, технологічний процес, будівельні роботи, об'єкт будівництва, інвестиційно-будівельний проект.

\section{АНАЛИЗ РИСКОВ, ВОЗНИКАЮЩИХ В ПРОЦЕССЕ СТРОИТЕЛЬСТВА}

Аннотация. Проанализированы риски, возникающие в процессе реализации инвестиционно-строительных проектов. Рассмотрена суть понятия риска, идентифицированы источники рисков, осуществлена классификация рисков по сфере возникновения (риски до завершения строительства, риски после завершения строительства). Представлены методы анализа рисков, возникающих в процессе реализации инвестиционно-строительных проектов: метод аналогий, метод статистического анализа, метод анализа чувствительности, экспертный метод, метод диаграмм, нормативный метод. Определены основные последствия реализации рисков и меры по их минимизации. Установлено, что принципиальное значение имеет объективный и беспристрастный анализ ситуации, сложившейся на инвестиционно-строительном рынке в контексте общего положения в соответствующем регионе и в стране в целом. Выявлена необходимость своевременной идентификации рисков, возникающих во время реализации проектов и определено их влияние на экономическую и эксплуатационную составляющие строительства. Рассмотрены основные механизмы управления рисками, представленные циклическими этапами, которые продолжаются от начала и до момента завершения проекта: выявление и определение риска; разработка шагов для снижения выявленных рисков; внедрение разработанного плана в проект; проведение анализа внедрения надзора за реализацией проекта. Использование представленных методов идентинтификации рисков будет способствовать повышению эффективности реализации инвестиционно-строительных проектов и уменьшению реальных затрат на реализацию проектов, предусмотренных сметной документацией путем определения возможных рисков, их идентификации и дальнейшем справедливом распределении идентифицированных рисков между участниками инвестиционно-строительных проектов.

В более детальных исследованиях приоритетным является вопрос разработки методологии управления рисками во время реализации инвестиционно-строительных проектов и внедрение матричного подхода к распределению рисков между участниками реализации проектов.

Ключевые слова: строительство, риск, управление рисками, нарушения, методы анализа рисков, технологический процесс, строительные работы, объект строительства, инвестиционно-строительный проект. 
Problem statement. The presentday environment where enterprises of the Ukrainian construction industry are functioning is extremely complicated. Competition, fast changes in the market situation, and unsteady political situation give rise to risks in the course of investment construction projects implementation.

As a consequence of the indefinite situation, it is impossible to avoid the risks occurring during construction. Success of investment construction projects fulfillment depends on how correctly can stakeholders of such projects find their way in complex situations and how negative factors will be foreseen and considered, which can affect project implementation. Top managers of an enterprise are not supposed to avoid a risk completely, they should foresee, assess, and mitigate its negative consequences to the minimum, which justifies a need to learn how to manage risks.

Analysis of the latest studies and publications. A considerable contribution to developing theoretical and applied problems of housing construction risk regulation has been made by foreign and Ukrainian scholars, namely V. Vitlinsky, P. Verchenko, M. Heley, Yu. Konovalov, Ya. Malyk, O. Myronov, O. Nepomnyashchyy, N. Reverchuk, S. Reverchuk, I. Yakhneyeva.

Purpose of the article. Purpose of this article is classifying the risks that occur during the implementation of investment construction projects.

Presentation of basic material. In construction, it is usual to observe typical failures to meet construction deadlines [1]. Notably, actual expenses for project implementation exceed the ones stipulated in the cost estimate. Discovering causes of such failures inevitably leads to analyzing the project fulfillment conditions and risks that affected it at various implementation stages. Therefore, it is very important to identify the risk sources instead of focusing on revealing separate factors of risk occurrence [2]. The most widespread causes of violations coming to pass during investment construction projects are deemed to be: owner's interference, insufficient experience of contractor, insufficient funding, low work performance, slow and unqualified decisionmaking, irrational planning, and subcontractors' incompetence [3].

The works dedicated to risk research including those in logistic systems and supply chains [4] list various parameters and essence of risks. On the grounds of this information, the following options of risk essence definition can be enumerated:

- Risk is a deviation from the expected course of events.

- Risk is a balance of possible revenues and losses, a balance of likely and unlikely threats of losses.

- Risk is a probability to fail to receive a revenue partially or completely should any unwanted events happen.

- Risk is a situation or event whose occurrence can cause deviations negative consequences, and simultaneously influence positively, i.e. have a positive effect.

At the same time, a risk probability or threat is presented in parameters whose evaluation allows determining the risk's significance. The latter option reflects the risk's core in the most comprehensive way and corresponds to the risk definition under the national 
standard ДСТУ ISO 9000:2015 (ISO 9000:2015, IDT): "Risk is an impact of indefiniteness, which shows in deviation from the expected result, either positive or negative" [4]. Risk is often characterized by a combination of events' consequences and occurrence probabilities related to them [4]. A probable risk is often defined in relation to potential events and their consequences or to a combination thereof. Simultaneously, the standard point out that indefiniteness is a state linked to a shortage (even partial) of information, comprehension, or awareness of an event, its consequences or probability. Due to that, of extreme importance in the organization management system is collection, storage, and analysis of actual information about external and internal risk factors.

It is noteworthy that the factors limiting business operations of construction companies are: shortage of works orders; competition from other companies; lack of qualified workers; high taxes; insolvency of clients; high cost of materials, structures, and products; insufficiency and worn-out condition of plant and equipment; high percentage of commercial credits [5]. To raise competitiveness of organizations in the construction field, it is necessary to work out a risk management mechanism that will make it possible to prevent the risks from happening. The risk management mechanism can be divided into 4 basic stages:

- виявлення i визначення ризику;

- розробка кроків для зниження виявлених ризиків;

- впровадження розробленого плану в проект;
- проведення аналізу впровадження нагляду за реалізацією проекту.

All the four stages are cyclic and last from the project commencement to it s completion. By the sphere of occurrence, the risks can be external and internal [5].

External risks are the risks caused by unfavorable influence from the macro environment or objects functionally linked to the building organization (banks, investors, suppliers, taxation authorities, etc.). Internal risks are the risks due to making wrong decisions that can be brought about by insufficient attention to analysis and planning of a building organization's operations, drawbacks of the current decisionmaking system, etc. The risks related to carrying out construction and installation works belong to internal risks of an organization. They are divided in two basic groups:

- category A - risks prior to construction completion;

- category B - risks after construction completion (not covered in this article). Herewith, category $B$ risks can result from manifestation of category A risks.

Category A risks lead to material losses thus increasing the cost of construction. Manifestation of these risks is connected with an imperfect quality management system in a construction company and failure to meet the set requirements.

Category A risks include:

- incompliance with the technological process during construction of buildings;

- using poor-quality building materials and/or structures; 
- exceeding time limits of construction.

In consequence of realizing the risk of incompliance with the technological process during buildings construction, it becomes necessary to rebuild the facilities under construction and/or completed facilities. The main measure to be taken to minimize such risks are:

- designer's supervision;

- client's control through involving a consulting engineer;

- establishing a system of penalty sanctions for the contractor's failure to perform the contracted obligations;

- contractor's insurance against mistakes during construction and installation, negligence of workers and technical staff;

- forming a financial reserve.

The risk of using low-quality building materials and/or structures can result in various kinds of defects up to destruction of facilities under construction and/or completed structures, which in their turn, make it possible to realize such risks as:

- inflicting damage on life and health of the construction staff;

- inflicting damage on life and health and/or property of third parties during construction works;

- litigations, etc.

As a result of realizing these risks, there occur extra costs, failures to meet project completion deadlines, and harm to business reputation. Basic measures to mitigate the risk of using inferior construction materials and/or structures are:

- control on the part of the developer, including one by involving a consulting engineer;
- establishing a system of penalty sanctions for the contractor's failure to perform the contracted obligations concerning use of poor-quality construction materials or products;

- setting a schedule of construction materials and technologies when concluding a contract with the contractor in order to prevent him from substituting lower quality ones for them;

- the contractor's insurance against possible destruction of structures under construction and/or completed structures;

- the contractor's insurance against possible killing of the building staff or third persons due to construction material defects;

- forming a financial reserve.

The risk of exceeding the construction time limits can arise in such conditions:

- insufficient funding;

- design errors;

- irregular supplies of construction materials;

- shortage of qualified staff, etc.

The risk consequences consist in unpredicted expenditures and delaying the facility's commissioning deadline. Main measures to be taken to minimize this risk are:

- designer's and engineer's supervision of construction;

- calendar planning of construction;

- developing alternative chains of construction materials supply;

- introducing a relevant system of sanctions for violating the workplace discipline;

- forming financial reserves.

In the construction field, it is reasonable to analyze risks on the basis of the below methods [3]: 
Analogy method. This method consists in the following: the information obtained from fulfillment of specific projects can be used in the future, especially if the project is a typical one. In particular, the data accumulated when building every stage of facilities is used during planning of works and supplies of goods and products for the next stage facilities.

Statistic analysis method. It can be applied together with other methods (first of all, the analogy method). This method is used to verify the risk influence hypotheses with the required information volume available, which determines frequency of an event occurrence and amount of the inflicted damage.

Sensitivity analysis method. This method allows assessing the influence of various factors on the project implementation milestones. In housing construction, such factors are change of cost prices, steady operation of technical means, regular procurement of construction materials, contractors' high quality performance. When the sensitivity analysis method is used, they evaluate boundary values of risk factors. Sensitivity analysis helps discover the factors that affect the project results at the most and choose the project implementation option which is the most risk-resistant.

Examination method. This method is based on analyzing and using the viewpoints that differ by their approaches to assess the risk parameters.

Diagram method. This method envisages making and analyzing the diagrams that reflect the relations of causes and consequences, making it possible to reveal the risk preconditions. Analysis of system diagrams or process diagrams demonstrates interrelation of different elements, factors, and mechanisms of causality.

Normative method. This method includes comparison of real risk parameters with the set normative values. Thus, limits of plant use at construction sites are stipulated in corresponding regulations, whose exceeding results in losses due to ineffective use of funds. In practice, it is quite challenging to keep all the listed risk sources in control. That is why a mandatory condition of effective risk management is operation of the information system with a separate subsystem of risk factors monitoring. Continuous input of relevant and true information to the system and its urgent processing allow timely reaction to changes at various levels. Effective process of managing the documented information in the quality management system is a prerequisite for effective risk management and mitigation of their effects on results of a building organization's operation.

Conclusions and prospects of further research. In unstable economic conditions, one can see a growing number of risks affecting the implementation of investment construction projects. These risks threaten such projects' stakeholders not only with essential decrease of revenues but also possible losses.

At the stage of risk identification, of crucial importance is analysis of the current situation at the investment construction market, as well as the overall state in the country and region to take preventive measures aimed at risk mitigation. Therefore one needs to identify the factors determining the 
level of risks that can be then classified by their corresponding categories and features.

Irrespective of the fact that it is impossible to take into account all risks that can arise while an investment construction project is being fulfilled, determination of risk analysis methods with a purpose of their structuring will advance effective realization of investment construction projects through identification and mitigation of risks occurring at all stages of project implementation, and also through their fair allocation.

In further studies, the priority in this matter should be given to developing a methodology of risk management during implementation of investment construction projects.

\section{REFERENCES}

1. Nepomniashchyi O. M., Medvedchuk O. V. (2018). Metodolohiia doslidzhennia derzhavnoho rehuliuvannia $\mathrm{v}$ konteksti upravlinnia ryzykamy u budivnytstvi [Methodology of the study of state regulation in the context of risk management in construction]. Menedzher. Visnyk Donetskoho derzhavnoho universytetu upravlinnia - Manager Bulletin of the Donetsk State University of Managemen, 1 (78), 15-19 [in Ukrainian].

2. Vitlinskyi V. V., Verchenko P. I. (2000). Analiz, modeliuvannia ta upravlinnia ekonomichnym ryzykom [Analysis, modeling and management of econo mic risk]. Kyiv: KNEU [in Ukrainian].

3. Systemy upravlinnia yakistiu. Osnovni polozhennia i slovnyk: DSTU ISO 9000:2015 (ISO 9000:2015, IDT) [Quality management systems. Basic provisions and vocabulary: DSTU ISO 9000: 2015 (ISO 9000: 2015, IDT)].
(2016). Kyiv: DP "UkrNDNTs" [in Ukrainian].

4. Yakhneeva I. V. (2012). Upravlinnia ryzykamy v lohistychnykh systemakh i lantsiuhakh postavok [Risk management in logistics systems and supply chains]. Samara: Vydavnytstvo SHEU [in Ukrainian].

5. Konovalov Yu. O., Myronov O. V. (2013). Systema upravlinnia ryzykamy: poniattia, funktsii, komponenty [Risk Management System: Concept, Functions, Components]. Innovatsiina Ekonomika - Innovative Economics, 9 (47), 127-132 [in Ukrainian].

6. Reverchuk S. K., Reverchuk N. Y., Malyk Ya. Y., Helei M. D. (2002). Ekonomichna bezpeka Ukrainy: vnutrishni i zovnishni chynnyky [Economic security of Ukraine: internal and external factors]. Lviv: Vyd. tsentr LNU imeni I. Franka [in Ukrainian].

\section{СПИСОК ВИКОРИСТАНИХ} ДЖЕРЕЛ

1. Системи управління якістю. Основні положення і словник: ДСТУ ISO 9000:2015 (ISO 9000:2015, IDT). [Чинний від 2016-07-01]. - Київ: ДП “УкрНДНЦ”, 2016. - IV, 45 с.

2. Непомнящий О. М. Методологія дослідження державного регулювання в контексті управління ризиками у будівництві / О. М. Непомнящий, О. В. Медведчук // Менеджер. Вісн. Донецького держ. ун-ту управління. -2018 . - № 1 (78). - С. 15-19.

3. Вітлінський В. В. Аналіз, моделювання та управління економічним ризиком: навч.-метод. посібник для самост. вивч. дисц. /В. В. Вітлінський, П. І. Верченко. - Київ: KHEУ, 2000. - $292 \mathrm{c}$.

4. Яхнеева I. В. Управління ризиками в логістичних системах і ланцюгах поставок. - Самара: Вид-во СГЕУ, 2012. - $126 \mathrm{c}$. 
5. Коновалов Ю. О., Миронов О. В. Система управління ризиками: поняття, функції, компоненти // Інноваційна Економіка. № 9 [47]. - 2013. - C. $127-$ 132.
6. Реверчук С. К., Реверчук Н. Й., Малик Я. Й., Гелей М. Д. Економічна безпека України: внутрішні і зовнішні чинники : навч. посіб. - Львів : Вид. центр ЛНУ імені І. Франка, 2002. $256 \mathrm{c}$. 